\title{
COMPARATIVE STUDIES ON EFFECT OF CARBON AND NITROGEN SOURCES ON L -ASPARAGINASE PRODUCTION
}

\author{
M. Mohamed Mahroop Raja ${ }^{{ }^{*}}$, A. Raja ${ }^{1}$, S. Mohamed Salique ${ }^{2}$, and P. Gajalakshmi ${ }^{3}$ \\ ${ }^{1}$ Department of Microbiology, Jamal Mohamed College (Autonomous), Tiruchirappalli, Tamil Nadu, India. \\ ${ }^{2}$ Department of Botany, Jamal Mohamed College (Autonomous), Tiruchirappalli, Tamil Nadu, India. \\ ${ }^{3}$ Department of Microbiology, Dhanalakshmi Srinivasan College of Arts \& Science for Women, Perambalur, Tamil Nadu, India.
}

*Corresponding author's email: mahroop_raja07@yahoo.co.in

\begin{abstract}
Marine actinomycetes sediment samples were collected from Gulf of Mannar costal region, Kayalpatinam, located at Tuticorin district, Tamilnadu, India. Marine actinomycetes were isolated and evaluated for activity of L-asparaginase production. A total of 10 marine actinomycetes strains were isolated. Among 10 isolates, six were belongs to Streptomyces sp, three were belongs to Micromonospora sp and one was to Micropolyspora sp. Based on phenotypic characteristics, actinomycetes strains were screened for L-asparaginase production. Streptomyces sp KPMS5 and Micromonospora sp KPMS10 were showed large pink coloration on L-asparaginase production medium. The strains were further studied for maximum production and characterizations of culture condition of L-asparaginase enzyme were evaluated. Effect of substrate on L-asparaginase production was evaluated by enzyme assy. Maximum enzyme assay (1.4 mM) was observed on glucose followed by starch $(1.12 \mathrm{Mm})$ by Micromonospora sp KPMS10. In Streptomyces sp KPMS5 showed maximum of $1.25 \mathrm{mM}$ of enzyme assay on glucose substrate followed by lactose $1.17 \mathrm{mM}$. Yeast extract was effectively used as substrate for maximum production of L-asparaginase by submerged fermentation. Further studies on purification and characterization are required to support the application of enzyme. The finding concludes isolates belongs to non-Streptomyces sp like Micromonospora sp is a potential novel source for L-asparaginase production.
\end{abstract}

Keywords: Leukemia; enzymes; L -asparagines; drugs; anticancer

\section{Introduction}

Many enzymes especially L-asparaginase has been attracted towards the use effective therapeutic agent against lymphocytic leukemia and many other types of cancer caused in human. Tumor cells is required to synthesis high amount of amino acid asparagines but it unable to synthesize their own, which is very closed for the better growth tumor cell, whereas non-tumor cell can synthesis their own asparagines and the cell growth is independent of its requirement (Pieters et al., 2011; Jha et al., 2012). Asparagine is a major component required for the synthesis of protein molecules. These can be synthesized by body itself, with in the cell by an enzyme called asparagines synthetase or can be taken from outside of the cell. Lasparaginase ( $\mathrm{L}$ - asparagines amidohydrolase E.C.3.5.1.1) is an enzyme which converts $\mathrm{L}$ - aspartic acid and ammonia has been used as a chemotherapeutic agent in the treatment of acute lymphoblastic leukemia there by prevents tumor cells from rapid malignant growth for over 30 years. These enzymes are selectively killed by L-asparagine deprivation. The clinical action of this enzyme is attributed to the reduction of L-asparagine (Amena et al., 2010). L- asparaginase production by microorganisms are basically used in clinical practices because the diversity of microbial population is being explored for gathering novel sources of L-asparaginase production with less side effects and better treatment(Geckil and Gencer, 2004).

Screening of microbial sources for L-asparaginase activity has been greatly intensified and well documented in filamentous fungi, yeast and bacteria like E.coli, Vibrio succinogenes, Erwinia carotovora (Deokar et al., 2010) and Bacillus sp. Among the fungi, Mucor sp., Penicillium sp., and yeast like Candida utilis have been proved to be potential producers of this enzyme (Joseph and Rajan, 2011).

Actinomycetes have gained special importance as the most potent source of bioactive secondary metabolites. Actinomycetes are group of thread like bacterial and look like fungi with high $\mathrm{G}+\mathrm{C}$ content which form branching filaments or hyphae and asexual reproduction (Peela et al., 2005). Some actinomycetes, Streptomyces karnatakensis, Streptomyces griseus (Dejong,1972), Streptomyces venezuelae, Streptomyces longsporusflavus, Streptomyces 
gulbargensis, marine Streptomyces sp PDK2 and Nocardia asteroids (Gunasekaran et al.,1995) have been reported to be a potential L-asparaginase synthesizer. Various scientists have described the role of L-asparaginase in the treatment of cancer and cancer biology. A vast amount of investment has been made for the enzyme to explore the new effective ways. This research focuses on the better understanding of the L-asparaginase production by marine actinomycetes.

\section{Methodology}

The isolation and identification of actinomycetes from marine sediments sample was collected from Gulf of Mannar costal region, Kayalpatinam, located at Tuticorin district, Tamil nadu, India. The marine sediments were collected and processed by serial dilution. One $\mathrm{ml}$ of diluted sample was permitted in to the starch casein agar medium supplemented with cyclohexamide $10 \mu \mathrm{g} / \mathrm{ml}$. Suspected actinomycetes were purified and identified by spore and biochemical properties.

\section{L-Asparaginase Production by Plate Assay (Gulati et al., 1997).}

Screening of marine actinomycetes for L-asparaginase production was performed on minimal medium incorporated with phenol red indicator by plate assay. This is the qualitative method used for L-asparaginase. The enzyme L-asparaginase was acted as substrate for Lasparaginase production. After incubation, the phenol red indicator turns pink zone around the colonies due to formation of ammonia at alkaline $\mathrm{pH}$ which indicates the production L-asparaginase.

\section{Optimization of L-Asparaginase Production}

The effect of carbon sources such as glucose, starch, lactose, mannitol and xylose on L-asparaginase production with peptone and yeast extract nitrogen sources was evaluated by submerged fermentation. The minimal media was prepared with $1 \%$ concentration of above mentioned carbon source. Two set up was prepared and one set up was supplemented with peptone $(0.1 \%)$ and another one with yeast extract. The growth rate and enzyme assay were performed after $24 \mathrm{~h}$.

\section{Purification of L-Asparaginase}

The purification of enzyme was carried out by using crude enzyme extract (Distasio et al., 1982). The enzyme purification was performed by ammonium sulphate precipitation. Finely powdered ammonium sulfate was added to the crude extract. The L-asparaginase activity was associated with the fraction precipitated at $80 \%$ saturation. The precipitated was collected by centrifugation at 9,000 rpm for $15 \mathrm{~min}$ and dissolved in $1 \mathrm{M}$ Tris- $\mathrm{HCl}$ buffer and dialyzed against the same buffer.

\section{Total Protein Estimation}

Estimation of protein was determined by using lowery et al method. A stock solution of standard protein, BSA at a concentration of $1000 \mu \mathrm{g} / \mathrm{ml}$ was made. From these aliquots, $0.2-1 \mathrm{ml}$ of working standard at concentration of
$100 \mu \mathrm{g} / \mathrm{ml}$ was taken in a test tube. All the test tubes were made up to $1 \mathrm{ml}$ with distilled water. $1 \mathrm{ml}$ of FC reagents was added to each test tube. After $30 \mathrm{~min}$ of incubation, the absorbance was measured at $660 \mathrm{~nm}$ by using UV-Vis spectrophotometer.

\section{Enzyme Assay}

The enzyme assay performed on M-9 broth medium for Lasparaginase enzyme production. The selected marine actinomycetes were sub cultured and inoculated in to M-9 broth medium. All the production flasks were kept at rotary incubator shaker for $72 \mathrm{~h}$. After incubation, $10 \mathrm{ml}$ of the cell suspension was taken and centrifuged. Quantitative detection was carried out by Nessler reagent method. $0.5 \mathrm{ml}$ of cell suspension, $1 \mathrm{ml}$ of $0.1 \mathrm{M}$ sodium borate buffer $(\mathrm{pH}$ 8.5 ) and $0.5 \mathrm{ml}$ of $0.04 \mathrm{M}$ L-asparaginase solution were mixed and incubated at $37 \mathrm{C}$ for $10 \mathrm{~min}$. The reaction was then stopped by the addition of $0.5 \mathrm{ml}$ of $0.1 \mathrm{~N}$ trichloroacetic acid. The precipitated protein was removed by centrifugation and the liberated ammonia was determined by direct nesslerization. Each sample was individually mixed with $1 \mathrm{ml}$ of $1 \mathrm{~N} \mathrm{NaOH}$ and $0.2 \mathrm{ml}$ of 0.1M EDTA was added. After $2 \mathrm{~min}, 0.5 \mathrm{ml}$ of nessler's reagent was added and mixed well. After 5 min, the addition of nessler's reagent to the sample, the yellow color was read on $117 \mathrm{UV}-\mathrm{Vis}$ spectrophotometer (Systronics) and the optical density of the sample was recorded at $450 \mathrm{~nm}$.

\section{Results and Discussion}

Totally 10 marine actinomycetes were isolated and identified as Micromonospora sp, Streptomyces sp and Micropolyspora sp (Table 1). All the marine actinomycetes were differing morphologically based on the color of colony, types of mycelium, spore and pigmentation. Among the ten isolates, six isolates were belongs to Streptomyces $\mathrm{sp}(60 \%)$ that are predominantly present in marine environments followed by three isolates were belongs to Micromonospora $\mathrm{sp}(30 \%)$ and one isolate to Micropolyspora sp (10\%).The dominance of Streptomyces sp is plentiful source in marine sediments and are reported by many workers (Lu et al., 2009; Hassan et al., 2011). Most of the strains produced spiral chains of spore are often spirally coiled and two of them were produced retractile spiral spore on substrate mycelium indicates the genera of Streptomyces sp. Mono spore was observed on actinomycetes colonies were belongs to the genera of Micromonospora sp was produced branched, non-motile and mono spore present only on substrate mycelium. The aerial mycelium was unstained by sudan black and the spore surface was smooth whereas the substrate mycelium was rough and stained by sudan black. The aerial mycelia were initially white and turned to ash, grey and dull white or chalky white on starch casein agar. The Micropolyspora $\mathrm{sp}$ KPMS 4 produced chain of spore with fragmented mycelium. All the isolated marine actinomycetes found in gram positive cell wall type. The group of actinomycetes 
was currently up dated with spore forming gram positive bacteria that form extensive branching substrate and aerial mycelia (Waksman, 1961).

Species among the genera were differentiated based on the physiological properties (Table 2). Among the Streptomycetes sp, three were found in catalase positive (KPMS2, KPMS5\& KPMS8). All Streptomyces sp were utilized starch and in oxidase except KPMS3. Similarly, Streptomyces sp of KPMS3 and KPMS6 were urease positive others were failed to obtain urease reaction. Among the Micromonospora sp, KPMS1were positive all types of physiological reaction. Similarly, KPMS9 was positive only in urease reaction and KPMS10 was negatively found in starch utilization. Micropolyspora sp KPMS4 was negatively found in catalase, oxidase, urease and partially positive in starch. Isolation and characterization of promising strain of marine actinomycetes research is a major area for many years in worldwide (Laidi et al., 2006).In this purpose, identification of genera and species of actinomycetes, besides morphological and physiological properties were performed for the potent identification of actinomycetes isolates(Kuster,1972; Abbas, 2006). Out of 10 isolates, 3 Streptomyces sp designated as KPMS 5, KPMS 6, KPMS 8 and one Micromonospora sp KPMS 10 were produced melanoid pigments. Actinomycetes are characterized by the production of various pigments on natural or synthetic media. The pigments may be dissolved in to the medium or it may be retained in the mycelium. Actinomycetes were known to be produced number of secondary metabolites and moreover these metabolites included many pigments .Production of pigments by marine actinomycetes has been utilized as an important cultural characteristic in describing the organisms (Miyaura and Tatsumi, 1960).

Table 1: Morphology of Isolated Marine Actinomycetes

\begin{tabular}{|l|l|l|l|l|l|}
\hline S.N. & $\begin{array}{l}\text { Strain } \\
\text { code }\end{array}$ & Spore morphology & $\begin{array}{l}\text { Color of aerial } \\
\text { mycelium }\end{array}$ & Cell wall type & Isolated Genus \\
\hline 1 & KPMS1 & Septate hyphae with monospore & Greenish grey & Gram positive & Micromonospora sp \\
\hline 2 & KPMS2 & Spiral chain of spore & White & Gram positive & Streptomyces sp \\
\hline 3 & KPMS3 & Long chain of spore & Ash & Gram positive & Streptomyces $\mathrm{sp}$ \\
\hline 4 & KPMS4 & $\begin{array}{l}\text { Chain of spore on fragmented } \\
\text { hyphae }\end{array}$ & Spiral chain of spore & Micropolyspora sp \\
\hline 5 & KPMS5 & Moderate length of chain of spore & Grey & Gram positive & Streptomyces $\mathrm{sp}$ \\
\hline 6 & KPMS6 & Sandal white & Gram positive & Streptomyces $\mathrm{sp}$ \\
\hline 7 & KPMS7 & Long chain of spore & Light grey & Gram positive & Streptomyces $\mathrm{sp}$ \\
\hline 8 & KPMS8 & Rarely branched spiral spore & Dull white & Gram positive & Micromonospora $\mathrm{sp}$ \\
\hline 9 & KPMS9 & Septate hyphae with monospore & Whites ash & Gram positive & Micromonospora $\mathrm{sp}$ \\
\hline 10 & KPMS10 & Septate hyphae with monospore & & Streptomyces $\mathrm{sp}$ \\
\hline
\end{tabular}

Table 2: Physiological characteristics of Isolated Marine Actinomyctes

\begin{tabular}{|l|l|l|l|l|l|l|}
\hline S.N. & Name of the Isolates & Catalase & Oxidase & Starch & Urease & Melanoid pigments \\
\hline 1 & Micromonospora sp KPMS1 & + & + & + & + & - \\
\hline 2 & Streptomyces sp KPMS2 & + & + & + & - & - \\
\hline 3 & Streptomyces sp KPMS3 & - & - & + & + & - \\
\hline 4 & Micropolyspora sp KPMS4 & - & - & \pm & - & - \\
\hline 5 & Streptomyces sp KPMS5 & + & + & + & - & + \\
\hline 6 & Streptomyces sp KPMS6 & - & + & + & + & + \\
\hline 7 & Streptomyces sp KPMS7 & - & + & + & - & - \\
\hline 8 & Streptomyces sp KPMS8 & + & + & + & - & + \\
\hline 9 & Micromonospora sp KPMS9 & - & - & - & + & - \\
\hline 10 & Micromonospora sp KPMS10 & + & + & - & + & + \\
\hline
\end{tabular}

+ : Positive; - :Negative; \pm : Partial 
All the ten actinomycetes were screened for L-asparaginase production at $37^{\circ} \mathrm{C}$ for $24-72 \mathrm{~h}$. Among 10 isolates, two isolated were showed L-asparaginase activity on plate assay method by pink colour zones formation around the actinomycetes growth which were belongs to genera of Streptomyces sp KPMS5 and Micromonospora sp KPMS10. Further, these isolates were subjected to secondary screening of enzyme activity. The production of L-asparaginase by various microorganisms using phenol red dye for screening techniques has been reported by other researcher (Sarquis et al., 2004). Marine Streptomyces is serving as good source of L-asparaginase enzyme and converts L-asparagine to L- aspartic acid and ammonia. It has been used as a chemotherapeutic agent (Fisher and Wray, 2002). Among them, Micromonospora sp KPMS10 showed higher activity. To the best of our knowledge, this is the first report on the production of L-asparaginase. The results was presented as marine actinomycetes are a good source of L-asparaginase productions .Our reports was accordance with other worker (Savitri et al., 2003).

The Streptomyces sp KPMS5 was able to use different carbon and nitrogen sources. Each carbon source and nitrogen source were incorporated in to basal medium at $1 \%$ and $0.1 \%$ concentration respectively. Among carbon sources, the maximum growth rate was found on glucose given an OD 1.58 with yeast extract by Streptomyces sp KPMS5 and least growth rate in xylose (OD 0.12). Among carbon sources supplemented with peptone, maximum growth of Streptomyces sp KPMS5 was 1.28 OD value and a minimum of $0.1 \mathrm{OD}$ value respectively for glucose and xylose (Fig. 1).

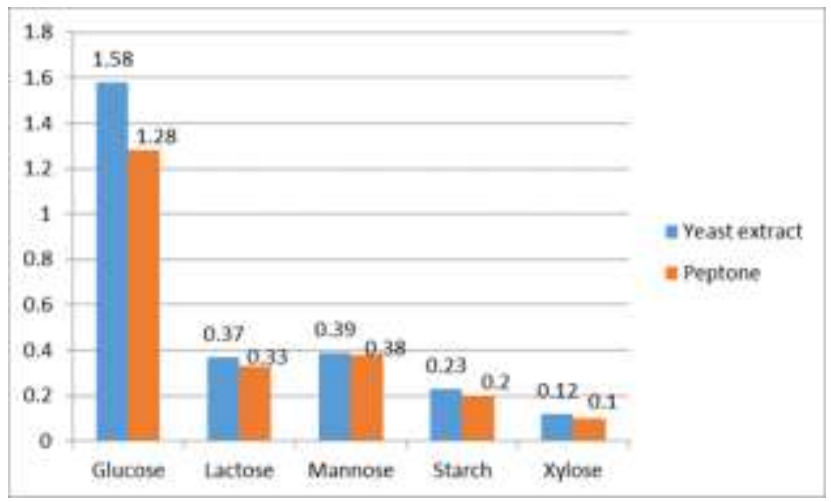

Fig. 1: Growth rate of Streptomyces sp KPMS5 on different carbon with yeast extract and peptone.

Similarly, Micromonospora sp KPMS10 to obtain the maximum growth rate was found on glucose at $1.18 \mathrm{OD}$ value by and less rate in xylose at 0.11 OD value with yeast extract as nitrogen source (Fig. 2). In various carbon sources along with peptone, the maximum growth rate was observed in $1.02 \mathrm{OD}$ value and a minimum of $0.1 \mathrm{OD}$ value respectively for glucose and xylose. As previously described, yeast extract has been used as a potent nitrogen source for production of enzymes L-asparaginase by Streptomyces albidoflavus and Streptomyces ginsengisoli.
The significant growth rate of Micromonospora sp KPMS10 and Streptomyces sp KPMS5 were showed on glucose with yeast extract. Production of enzymes Lasparaginase was highly found in the presence of glucose as carbon substrate by a river isolate of Streptomyces ginsengisoli (Neelima Deshpande et al., 2014). Among the carbon source, glucose, lactose and starch were found to be suitable for growth of actinomycetes whereas xylose was significantly affect the growth rate.

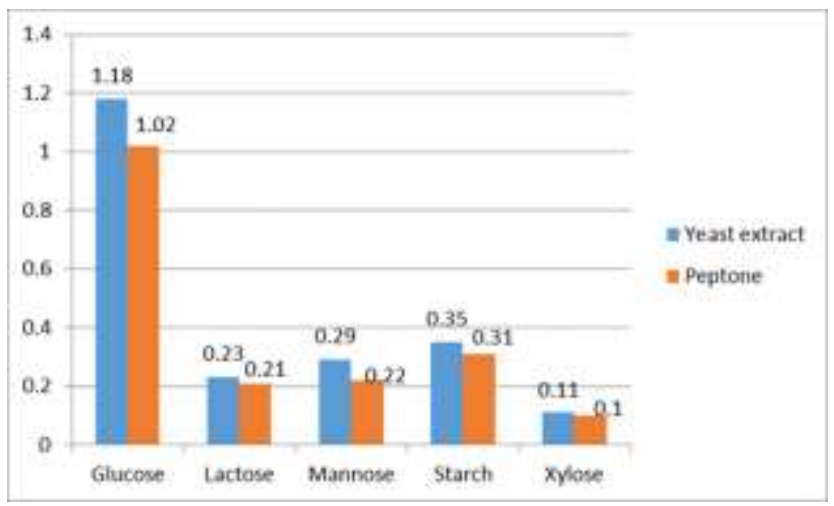

Fig. 2: Growth rate of Micromonospora sp KPMS10 on different carbon with yeast extract and peptone.

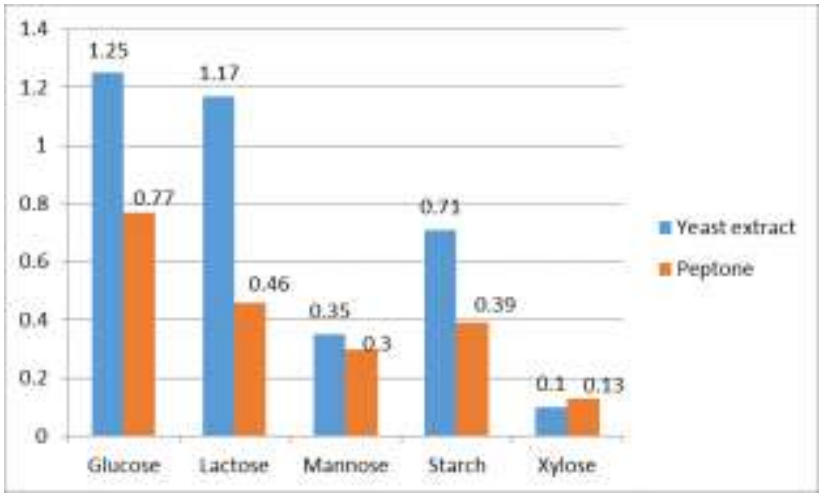

Fig. 3: L-asparaginase assay of Streptomyces sp KPMS5 with yeast extract and peptone

The enzyme assay of Nessler's method reveals that the strain Micromonospora sp KPMS10 was found to be maximum extracellular $\mathrm{L}$ asparaginase producer than Streptomyces sp KPMS5 under submerged conditions. The maximum enzymatic activity of Micromonospora sp KPMS10 was found in $1.4 \mathrm{mM}$ on glucose followed by $1.12 \mathrm{mM}$ on starch and minimum of $0.1 \mathrm{mM}$ on xylose with yeast extract. In peptone source, Micromonospora sp KPMS10 was found in $1.13 \mathrm{mM}$ on glucose followed by $0.96 \mathrm{mM}$ on starch and minimum of $0.1 \mathrm{mM}$ on xylose (Fig. 3 ). The Streptomyces sp KPMS5 was found a maximum of $1.25 \mathrm{mM}$ on glucose followed by $1.17 \mathrm{mM}$ on lactose and minimum of $0.1 \mathrm{mM}$ on xylose with yeast extract source. In peptone source, Streptomyces sp KPMS5 was found $0.77 \mathrm{mM}$ on glucose followed by $0.46 \mathrm{mM}$ on lactose and least of $0.13 \mathrm{mM}$ on xylose (Fig. 4). Micromonospora $\mathrm{sp}$ are potential actinomycetes to produce secondary metabolite with diverse chemical structure and biological activity. Currently, diazepinomicin is a unique farnesylated 
dibenzodiazepinone and used as anticancer metabolite are derived from marine actinomycetes Micromonospora $\mathrm{sp}$ (Charan et al., 2004).The potential actinomyctes exhibited both intra and extracellular production of L-asparaginase by Streptomyces longsporusflavus(Abdel-Fattah and Olama,1998).

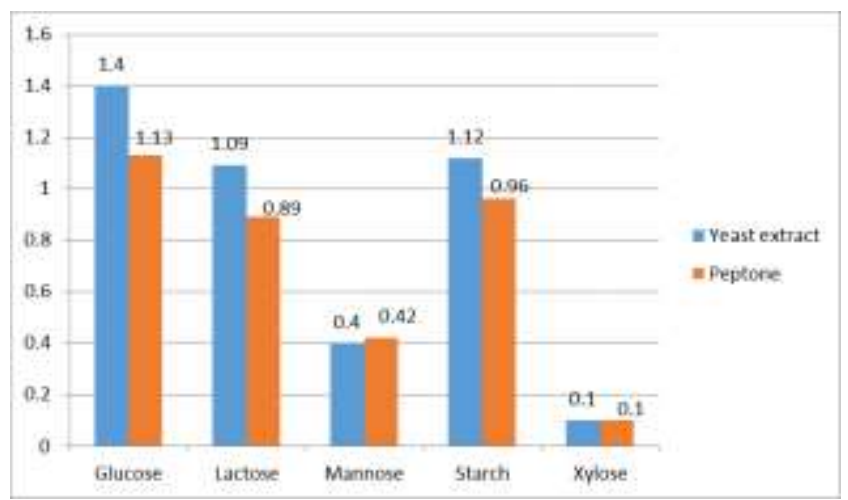

Fig. 4: L-asparaginase assay of Micromonospora sp KPMS10 with yeast extract and peptone.

Difference on production of L-asparaginase with yeast extract and peptone was observed and evaluated at $24 \mathrm{~h}$. Among the two nitrogen sources, maximum enzymatic activity was found on yeast extract source given by Micromonospora sp KPMS10 and Streptomyces sp KPMS5.Yeast extract has been reported as a good nitrogen source for the production of L-asparaginase by Streptomyces albidoflavus (Narayana et al., 2008). Lasparaginase activity in Streptomyces sp isolated from the foregut and hindgut region of clam, V.cyprinoids (Mathew et al., 1994; Koshy et al., 1997). The maximum rate of Lasparaginase production by Amycolatopsis CMU-H002 was amended with starch as the carbon source (Khamna et al., 2009). Among the carbon source, glucose and starch showed the immediate conversion of L-asparagines into ammonia was observed within $24 \mathrm{~h}$ under submerged condition. The higher enzymatic activity occurred in submerged fermentation by Streptomyces sp (Sahu et al., 2007). Carbon sources except xylose and other sugar molecules showed L-asparaginase enzymes activity to be found after $48 \mathrm{~h}$ of incubation. The least L-asparaginase activity was found on xylose as from $0.1 \mathrm{mM}$ by both tested actinomycetes.

The L-asparaginase was partially purified by ammonium sulphate precipitation and analyzed further for characterization of protein. The total protein content was found to be $2 \mathrm{mg} / \mathrm{ml}$ and $1.8 \mathrm{mg} / \mathrm{ml}$ for Streptomyces $\mathrm{sp}$ KPMS5 and Micromonospora sp KPMS10. The production and purification of L-asparaginase by marine actinomycetes Streptomyces tendae TK-VL-333 isolated from sediment samples of Parangipettal and Cochin coastal region in South India has been reported (Kavitha and Vijayalakshmi, 2010). The isolate PDK7 and PDK8 from Parangipettal and Cochin coastal region in South India, were gave potential Lasparaginase activity (Dhavala et al., 2006). Similarly, among 10 actinobacterial strains, three isolate S3, S4 and S8 belongs to Streptomyces sp were showed extracellular production of anti-leukemic enzyme L-asparaginase (Basha et al., 2009). Several terrestrial Streptomyces are capable of producing detectable amounts of L-asparaginase. There are limited reports on production of L-asparaginase from marine Streptomyces like Streptomyces aurantiacus (Gupta et al., 2007). Streptomycetes and Micromonospora sp are distributed in both marine and terrestrial environments. They have unique features to produce novel bioactive metabolites such as antibiotics, enzymes and antitumor compounds (Mitchell et al., 2004).

\section{Conclusion}

Marine actinomycetes are one of the most eminent secondary metabolites synthesizers and are very important in industrial point of view. Enzyme after antibiotics are most important metabolites derived from actinomycetes. This study concludes that Streptomycetes $\mathrm{sp}$ and Micromonospora sp is an efficient producer of Lasparaginase. Marine actinomycetes are well organized synthesizer of both extracellular and intracellular Lasparaginase and holds potential for treatment of acute lymphocytic leukemia and cancer in other types. With the increasing advancement in modern science, there would be a greater demand for new metabolites synthesized from marine action bacteria in future.

\section{Acknowledgement}

We thank the Department of Microbiology, Jamal Mohamed College (Autonomous), Tiruchirappalli-620020, for supporting and fulfilling all the needs to carry out this work.

\section{References}

Abbas IH (2006) A biological and biochemical studies of Actinomycetes isolated from Kuwait saline soil-Kuwait. Journal Applied Science Research 2: 809-815.

Abdel-Fattah YR and Olama ZA (1998) Studies on the asparaginolytic enzymes of Streptomyces. Egypt Journal of Microbiology 30: 155-159.

Amena S, Vishalakshi N, Prabhakar M, Dayanand A and Lingappa K (2010) Production, purification and characterization of L- asparaginase from Streptomyces gulbargenesis. Brazilian Journal of Microbiology. 41(1): 173-178. DOI: 10.1590/S1517-83822010000100025

Basha SN, Rekha R, Komala M and Ruby S (2009) Production of extracellular anti-leukaemic enzyme L-asparagenase from marine actinomycetes by solid-state and submerged fermentation: Purification and Characterization. Tropical Journal of Pharmaceutical Research 8: 353-360. DOI: 10.4314/tjpr.v8i4.45230

Charan RD, Schlingmann G, Janso J and Carter GT (2004) Diazepinomicin, a new antimicrobial alkaloid from a marine Micromonospora sp. Journal of Nature Product. 67: 1431-1433. DOI: $10.1021 / \mathrm{np} 040042 \mathrm{r}$

Dejong PJ (1972) L-asparaginase production by Streptomyces griseus. Applied Microbiology 23(6): 1163-1164. 
Deokar VD, Vetal MD and Lambert R (2010) Production of intracellular L-asparaginase from Erwinia caratovora and its statistical optimization using response surface methodology. International Journal of Chemical Science and Application 1(1): 25-26.

Dhavala P, Krasotkina J, Dubreuil C and Papageorgiou AC (2006) Isolation and characterization of L-asparagenase from marine actinomycetes. Indian Journal of Biotechnology $\mathbf{5}$ : 514-520.

Distasio JA, Salazar AM, Nadji M and Durden DL (1982) Glutaminase-free asparaginase from Vibrio succinogenes: an antilymphoma enzyme lacking hepatotoxicity. International Journal of Cancer. 30(3):343-347. DOI: 10.1002/ijc. 2910300314

Fisher SH and Wray LV (2002) Bacillus substilis 168 contains two differentially regulated genes encoding L-asparaginase. Journal of Bacteriology. 184: 2148-2154. DOI: 10.1128/JB.184.8.2148-2154.200

Geckil H and Gencer S (2004) Production of L-asparaginase in Enterobacter aerogenes expressing Vitreoscilla hemoglobin for efficient oxygen uptake. Applied Microbiology and Biotechnology. 63(6):691-697. DOI: 10.1007/s00253-003-1482-5

Gulati R, Saxena RK and Gupta R(1997) A rapid plate assay for screening L-asparagenase producing microorganisms. Letters in Applied Microbiology. 24(1):23-26. DOI: 10.1046/j.1472-765X.1997.00331.x

Gunasekaran S, Mc Donald L, Manavathu M, Manavathu E and Gunasekaran M(1995) Effect of culture media on growth and L-asparaginase production in Nocardia asteroids. Biomedical Letter. 52(207): 197-201.

Gupta N, Mishra S and Basak UC (2007) Occurence of Streptomyces aurantiacus in mangroves of Bhitarkanika. Malaysian Journal of Microbiology. 3:7-14.

Hassan AA, El-Barawy AM, Mokhtar EL and Nahed M (2011) Evaluation of biological compounds of Streptomyces sp for control of some fungal diseases. Journal of American Science. 7:752-60.

Jha SK, Pasrija D, Sinha RK, Singh HR, Nigam VK and Vidyarthi AS (2012) Microbial L-asparaginase: a review on current scenario and future prospects. International Journal of Pharmaceutical Sciences and Research 3(9): 3076.

Joseph B and Rajan SS (2011) L-Lysine alpha oxidase from fungi as an anti tumor enzyme agent. Advanced Biotechnology $10(8): 27-30$

Kavitha A and Vijayalakshmi M (2010) Optimization and purification of L-asparaginase produced by Streptomyces tendae TK-VL 333. Z Naturforsch. 65c:528-531.

Khamna S, Yokota A and Lumyong S (2009) L-asparaginase production by actinomycetes isolated from some Thai medicinal plant rhizosphere soils. International Journal of Integrative Biology 6(1): 22-26.

Koshey A, Dhevendaran K, Geogekutty MI and Natarajan P (1997) L-asparaginase in Streptomyces plicatus isolated from the alimentary canal of the fish, Gerres filamentosus (Cuvier). Journal of Marine Science. 5:181-185.
Kuster E (1972) Simple working key for the classification and identification of named taxa included in the international Streptomyces project. International Journal of Systematic Bacteriology 22: 139-148. DOI: 10.1099/00207713-22-3139

Laidi RF, Kansoh AL, Elshafei AM and Cheikh B (2006) Taxonomy, Identification and biological activities of novel isolate of Streptomyces tendae. Arab Journal of Biotechnology. 9: 427-436.

Lu Y, Dong X and Liu S (2009) T-muurolol sesquiterpenes from the marine Streptomyces sp M491 and revision of the configuration of previously reported amorphanes. Journal of Natural Product .72:99-101. DOI: 10.1021/np8006843

Mathew A, Dhevendaran K, Geogekutty MI and Natarajan P (1994) L-asparaginase activity in antagonistic Streptomyces $\mathrm{sp}$ associated with clam villorita cyprinoides (Hanley). Indian Journal of Marine Science. 23:204-208.

Mitchell SS, Nicholson B, Teisa S, Lam KS and Potts BC(2004) Aureoverticillactam, a novel 22-atom macrocyclic lactam from the marine actinomycetes Streptomyces aureoverticillatus. Journal of Natural Product .67:14001402. DOI: $10.1021 / \mathrm{np} 049970 \mathrm{~g}$

Miyaura J and Tatsumi C (1960) Studies on the antibiotics from actinomycetes an antibiotics pigments from Streptomyces F-23b. Bull Univ Osaka Pref Ser B. 1: 129-137.

Narayana KJP, Kumar KG and Vijayalakshmi M (2008) Lasparagenase production by Streptomyces albidoflavus. Indian Journal of Microbiology. 48:331-336. DOI: $10.1007 / \mathrm{s} 12088-008-0018-1$

Neelima Deshpande, Prachi Choubey and Manasi (2014) Agashe studies on optimization of growth parameters of Lasparaginase production by Streptomyces ginsengisoli. Scientific World Journal .89:51-67.

Peela S, Kurada VVSNP and Terli R (2005) Studies on antagonistic marine actinomycetes from the bay of Bengal. World Journal of Microbial Biotechnology. 21:583-585. Doi: 10.1007/s11274-004-3493-5

Pieters R, Hunger SP, Boos J, Rizzari C, Silverman L and Baruchel A (2011) L-asparaginase treatment in acute lymphoblastic leukemia: a focus on Erwinia asparaginase. Cancer. 117(2):238-242. DOI: $10.1002 /$ cncr.25489.

Sahu MK, Sivakumar K, Poorani E, Thangardjou T and Kannan L(2007) Studies on L-asparaginase enzyme of actinomycetes isolated from estuarine fishes. Journal of Environmental Biology. 28(2S):465-474.

Sarquis MI, Oliveira EM, Santos AS and Costa GL (2004) Production of L-asparaginase by filamentous fungi. Mem Inst Oswaldo Cruz. 99:489-492. DOI: 10.1590/S007402762004000500005

Savitri, Neeta Astana and Wamik Azmi (2003) Microbial Lasparagenase:a potent anti tumor enzyme. Indian Journal of Biotechnology. 2:184-194.

Waksman SA (1961). The Actinomycetes: Classification, Identification and Description of genera and species. Baltimore: Lippicncott Williams and Wilkins. 2:377-375. 